\title{
Assessment of validation and antioxidant activities of novel 12 Korean strawberry cultivars
}

\author{
Songmi LEE ${ }^{1 \ddagger}$, Joong-Hyun $\mathrm{CHO}^{2 \ddagger}$, Ki Deok PARK ${ }^{3,4}$, Yong-Dae KIM ${ }^{4}$, Soon-Ho YIM ${ }^{4 \star}$
}

\begin{abstract}
In this study, antioxidant activities of extracts of 12 Korean strawberry cultivars were evaluated and validation of an analytical method for ellagic acid, a marker compound, was carried out. Cultivar 'Josaenghongshim' had the highest total polyphenol and flavonoid contents. In addition, cultivar 'Josaenghongshim' had the highest value and cultivar 'Seolhyang' showing the highest activity. Ellagic acid contents of 'Suhong,' 'Okme', and 'Dahong' cultivars were the highest ellagic acid content. Correlation coefficient of the calibration curve was 0.9999 , showing very high linearity. The HPLC-DAD method for the quantitation of ellagic acid content showed high linearity at various concentration ranges, with a limit of detection of $2.35 \mu \mathrm{g} / \mathrm{mL}$. The limit of quantification was $7.13 \mu \mathrm{g} / \mathrm{mL}$. Relative standard deviations from intra- and inter-day precision were less than $5.13 \%$. Recovery rates of ellagic acid at 10,50 , and $100 \mu \mathrm{g} / \mathrm{mL}$, respectively, were $99.0-100.1 \%$ with RSD values less than $5.30 \%$. These results provide viable information for the validation of antioxidant capacities of 12 cultivars of Korean strawberries.
\end{abstract}

Keywords: antioxidant; validation; marker compounds; Korean strawberries; ellagic acid.

Practical Application: Development of a new variety of strawberry with excellent antioxidant effect.

\section{Introduction}

Reactive oxygen species (ROS) such as superoxide anion radical $\left(\mathrm{O}_{2}^{-}\right)$, hydroxy radical $\left(\cdot \mathrm{OH}^{-}\right)$, and hydrogen peroxidase $\left(\mathrm{H}_{2} \mathrm{O}_{2}\right)$ produced by various metabolic processes. There are known to cause human diseases and aging (Hwang et al., 2014). Excessively produced ROS can lead to severe physiological disabilities by damaging tissues and cells, and inhibiting protein breakdown and DNA synthesis (Halliwell et al., 1992). Living organisms have antioxidant systems such as superoxide dismutase (SOD), catalase, glutathione reductase, glutathione, and thioredoxin to protect cells against damages caused by ROS (Sies, 1993). However, needs of safe and effective antioxidants are increased for stressed-out modern people (Lee \& Lee, 2016). Recently, due to improvement of living standard and change in consumer perception, functional food materials developed from natural product and related research are increased (Lee et al., 2015).

Strawberry (Fragaria ananassa Duch.), a perennial plant belonging to the rose family, has high contents of sugars, organic acids, and bioactive compounds such as ascorbic acid, polyphenols, quercetin, ferulic acid, ellagic acid, and flavonols (Kim et al., 2015). Consuming strawberries can reduce the risk of chronic diseases such as cancers (Seeram et al., 2006), cardiovascular diseases (Azzini et al., 2010), and memory loss (Giampieri et al., 2012). It can also decrease mutation and cholesterol level (Meyers et al.,
2003). Among all polyphenols in strawberries, ellagic acid has a strong antioxidant efficacy by scavenging free radicals (Türk et al., 2010). It also possesses antiviral and antibacterial properties. It can also protect cells against apoptosis (Xu et al., 2003). Ellagic acid may produce positive effects in the control of estrogen receptor, collagen expression, and inhibition of photoresistance damage in fibroblasts (Kim et al., 2016; Türk et al., 2010; Papoutsi et al., 2005). In addition, ellagic acid can prevent tissue damage by repress peroxide lipid formation and control carcinogenesis by promoting the activity of detoxification enzyme (Maas et al., 1991). It also has protective effect against skin cancer (Mukhtar et al., 1986), and liver cancer (Shimogaki et al., 2000).

Although many studies have been conducted on ellagic acid using HPLC, only a few studies have been conducted on strawberry varieties (Yong et al., 2019). The objective of this study was to investigate antioxidant effects of 12 cultivars of strawberries grown and harvested by the National Institute of Horticultural and Herbal Science and chungcheongnamdo agricultural research \& extension. In addition, we performed a validation of content analysis method for ellagic acid to obtain basic data that would aid the development of natural antioxidants and marker components of ellagic acid in various strawberry varieties. 


\section{Materials and methods}

\subsection{Chemical and reagents}

Folin-Ciocalteu reagent, tannic acid, quercetin, ellagic acid, 2,2'-azino-bis-3-ethylbenzothiazoline-6-sulfonic acid (ABTS), 1,1-diphenyl-2-picrylhydrazyl (DPPH), and (+/-)-6-hydroxy2,5,7,8-tetramethylchromane-2-carboxylic acid (trolox) were obtained from Sigma-Aldrich Co. (St. Louis, MO, USA). For ellagic acid analysis, methanol and acetonitrile were obtained from J. T. Baker (Phillipsburg, NJ, USA). All other chemicals used were special grade reagents.

\subsection{Plant materials and extraction}

Twelve cultivars of Korean strawberries grown and harvested by the National Institute of Horticultural and Herbal Science and chungcheongnamdo agricultural research \& extension in 2017 were used as samples in this study (Table 1 ). These 12 cultivars of strawberry samples used in this study were harvested from red-colored hard-boiled fruits with similar growth period. Strawberry samples were extracted with $10 \mathrm{vol}(\mathrm{v} / \mathrm{w})$ of water at $80^{\circ} \mathrm{C}$ for $3 \mathrm{~h}$, and extraction was repeated 3 times. Extracts were concentrated with vacuum evaporator (COSMOS66050L, Kyungseo Machines Co, Incheon, Korea), and frozen in a deep freezer at $-70{ }^{\circ} \mathrm{C}$ for $24 \mathrm{~h}$, freeze-dried and stored at $4^{\circ} \mathrm{C}$ for use in the experiment. Each dried extraction, it was then dissolved in a pretreatment solvent (ethanol: distilled water: $\mathrm{HCI}=3: 1: 1$ ) and hydrolyzed for $3 \mathrm{~h}$ at $90^{\circ} \mathrm{C}$. The extracted solution was then cooled to at room temperature and filtered with a syringe filter $(0.45 \mu \mathrm{m}$, Hyundaimicro Co., Ltd, Korea) to obtain as a test solution.

\subsection{Determination of total polyphenol content}

Total polyphenol contents were measured applying the modified method of Folin-Ciocalteu method (Singleton et al., 1999). Each sample solution $(500 \mu \mathrm{L})$ was mixed Folin-Ciocalteu reagent $(500 \mu \mathrm{L})$ for $3 \mathrm{~min}$, added with $10 \% \mathrm{Na}_{2} \mathrm{CO}_{3}(500 \mu \mathrm{L})$, incubated at room temperature for $1 \mathrm{~h}$, and then subjected to measurement of absorbance at $760 \mathrm{~nm}$ using a UV/VIS spectrophotometer (Neogen, Optizen 2120 UV, Sejong, Korea). Total polyphenol content (mg TAE/100 g fresh weight (FW))

Table 1. Parentage and Origin of 12 strawberry cultivars.

\begin{tabular}{cccc}
\hline NO & Cultivar & Parentage & Origin \\
\hline 1 & Berrystar & Ssanta $\times 07-S-28$ & Korea $(2014)$ \\
2 & Chodong & Halunoka $\times$ Palcheondae & Korea (1986) \\
3 & Dahong & Sachinoka $\times$ Maehyang & Korea (2007) \\
4 & Dummy & Unknown & Korea \\
5 & Johong & Yeobong $\times$ Akihime & Korea (2002) \\
6 & Josaenghongsim & Honghag $\times$ Useusino & Korea (1982) \\
7 & Manhyang & Yeobong $\times$ Akkanekko & Korea (2003) \\
8 & Mihong & Toyonoka $\times$ Yeohong & Korea (1996) \\
9 & Okme & Toyonoka $\times$ Maehyang & Korea (2010) \\
10 & Seolhyang & Akihime $\times$ Red Pearl & Korea (2005) \\
11 & Sinseolmae & Seolhyang $\times$ Geumhyang & Korea (2012) \\
12 & Suhong & Hogyojosaeng $\times$ Chunhyang & Korea (1985) \\
\hline
\end{tabular}

was obtained using a standard curve prepared with tannic acid as the standard substance.

\subsection{Determination of total flavonoid contents}

Total flavonoid contents were determined using the Moreno method (Moreno et al., 2000). Briefly, each sample $(10 \mu \mathrm{L})$ was diluted with $80 \%$ ethanol $(990 \mu \mathrm{L})$. Then $100 \mu \mathrm{L}$ of this sample solution was mixed with $80 \%$ ethanol solution $(4.3 \mathrm{~mL})$ containing of $10 \%$ aluminum nitrate and $1 \mathrm{M}$ potassium acetate for $40 \mathrm{~min}$. Absorbance was then measured at $415 \mathrm{~nm}$ using a spectrophotometer (Mecasys Co., Daejeon, Korea). Total flavonoid content (mg QE/100 g FW) was obtained using a standard curve prepared with quercetin as the standard substance.

\subsection{DPPH radical scavenging activity}

DPPH radical scavenging activity is one indicator of electron-donating ability. It was measured applying the modified method of Brand-Williams et al. (1995). The sample solution (10 $\mu \mathrm{L} /$ well $)$ and $0.2 \mathrm{mM} \mathrm{DPPH}(190 \mu \mathrm{L} /$ well $)$ were added into a 96 -well plate. After incubation at $25^{\circ} \mathrm{C}$ for $30 \mathrm{~min}$, absorbance was measured at $515 \mathrm{~nm}$ using an ELISA reader (Thermo Fisher SCIENTIFIC, Multiskan Sky, KOREA).

\subsection{ABTS radical scavenging activity}

ABTS radical scavenging activity is one indicator of electrondonating ability. It was measured with modified method of Thaipong et al. (2006). Briefly, $7 \mathrm{mM} \mathrm{ABTS}$ and $2.45 \mathrm{mM}$ potassium persulfate were mixed at a ratio of $1: 1(\mathrm{v} / \mathrm{v})$ to react in a dark room at $25^{\circ} \mathrm{C}$ for $24 \mathrm{~h}$ to generate radicals. Radical stock solution was diluted with distilled water so that the absorbance value at $734 \mathrm{~nm}$ was $0.70 \pm 0.02$. After incubation in a dark room at $25^{\circ} \mathrm{C}$ for $5 \mathrm{~min}$, absorbance was measured at $734 \mathrm{~nm}$ using a UV/VIS spectrophotometer (Neogen, Optizen 2120 UV, Sejong, Korea).

\subsection{Prepare of standard solution}

Ellagic acid analytical standard with a purity of $95 \%$ was dissolved in $1 \times 10^{-2} \mathrm{~N} \mathrm{NaOH}$ and store at $4^{\circ} \mathrm{C}$. A standard solution was made by dilution so that the concentration of this solution was in the range of $10-100 \mu \mathrm{g} / \mathrm{mL}$.

\subsection{Method validation}

Validation of analysis methods for marker components was performed by determining linearity, limit of detection (LOD), limit of quantitation (LOQ), accuracy, and precision according to guidelines of analysis methods used for medicines (Korean Food and Drug Administration, 2015).

- Linearity, limit of detection, and limit of quantitation Ellagic acid standard solution (five concentrations) was used to determine coefficient $\left(\mathrm{R}^{2}\right)$ using retention time and regression equation $(y=a x+b$, $y$ : peak area, $x$ : concentration $(\mu \mathrm{g} / \mathrm{mL}))$ shown on HPLC. Limit of detection and limit of quantitation for each component were determined based 
on the standard deviation and the slope of the calibration curve using chromatogram of the standard solution;

- Accuracy and precision Accuracy and precision were evaluated to determine inter-day and intra-day variations of the index component at the same concentration. Accuracy refers to the proximity of average test results obtained by the analysis method. Relative standard deviation was calculated by measuring each sample three times for each concentration $(10 \mu \mathrm{g} / \mathrm{mL}, 50 \mu \mathrm{g} / \mathrm{mL}$, and $100 \mu \mathrm{g} / \mathrm{mL})$. Precision indicates the proximity between measured values when a sample is taken several times and measured under specified conditions. It was measured with relative standard deviation which was obtained by measuring the standard solution at each concentration $(0,50$, and $100 \mu \mathrm{g} / \mathrm{mL}$ ) three times;

- Stability To check chemical stability of ellagic acid according to the storage period, each sample was kept at room temperature for $24 \mathrm{~h}$, and then ellagic acid content was measured.

\subsection{Ellagic acid content analysis}

Ellagic acid contents in strawberry extracts were analyzed using high performance liquid chromatography (HPLC, Agilent Technologies, Santa Clara, CA, USA) with an autosampler and a DAD detector. Analysis conditions are shown in Table 2. Analysis was done using YMC ODS column $(4.6 \times 250 \mathrm{~mm}$, Kyoto, Japan) and tertiary distilled water containing $0.1 \%$ formic acid (solvent A) and 100\% acetonitrile (solvent B) as mobile phase. Measurements were made at $254 \mathrm{~nm}$ wavelength with a flow rate of $1 \mathrm{~mL} / \mathrm{min}$ and $10 \mu \mathrm{L}$ of sample for injection.

\subsection{Statistical analysis}

Experimental data of this study are expressed as mean \pm standard deviation after three repeated experiments. Difference between groups was determined by one-way variance analysis and Duncan's multiple range test using SPSS (statistical package for the social sciences, ver. 25). Statistical significance was considered at $p<0.05$.

Table 2. Analytical conditions of HPLC for ellagic acid analysis.

\begin{tabular}{|c|c|c|c|}
\hline Parameters & & \multicolumn{2}{|c|}{ Conditions } \\
\hline Column & & \multicolumn{2}{|c|}{ YMC ODS $5 \mu \mathrm{m} 250 \times 4.6 \mathrm{~mm}$} \\
\hline Flow rate & & \multicolumn{2}{|c|}{$1 \mathrm{~mL} / \mathrm{min}$} \\
\hline $\begin{array}{l}\text { Injection } \\
\text { volume }\end{array}$ & & \multicolumn{2}{|c|}{$10 \mu \mathrm{L}$} \\
\hline UV detection & & \multicolumn{2}{|c|}{$254 \mathrm{~nm}$} \\
\hline \multirow[t]{4}{*}{ Run time } & & \multicolumn{2}{|c|}{$40 \mathrm{~min}$} \\
\hline & Time (min) & $\mathrm{A}(\%)$ & B (\%) \\
\hline & 0 & 90 & 10 \\
\hline & 5 & 90 & 10 \\
\hline \multirow{4}{*}{$\begin{array}{l}\text { Gradient } \\
\text { condition }\end{array}$} & 25 & 40 & 60 \\
\hline & 30 & 20 & 80 \\
\hline & 35 & 90 & 10 \\
\hline & 40 & 90 & 10 \\
\hline
\end{tabular}

\section{Results and discussion}

\subsection{Determination of phenolic compounds}

Phenolic compounds contained in fruits provide general quality (such as color and taste) and health functions (such as antioxidant) of fruits. They are important ingredients that can protect plants from infections by bacteria and viruses. They can also extend the storage period (Tosun et al., 2009). In this study, total polyphenol contents present in strawberry extracts were measured using tannic acid as a reference substance for quercetin (Table 3 ). Total polyphenol contents ranged from 21.79 to $118.85 \mathrm{mg}$ TAE/100 g FW, with 'Josaenghongsim' cultivar showing the highest total polyphenol contents among all cultivars tested, followed by 'Okme' and 'Chodong', whereas 'Manhyang', 'Sinseolmae', and 'Johong' cultivars had the lowest total polyphenol contents. Significant $(p<0.05)$ differences in total polyphenol content were found among strawberry cultivars. Scalzo et al. (2005) have reported that total polyphenol contents in six Italian strawberry cultivars ('Don', 'Idea', 'Camarosa', 'Onda', 'Patty', and 'Svev') are in the range of 1,093 2,128 mg GAE/L. Pineli et al. (2011) have also reported that total polyphenol contents in 'Osogrand' and 'Camino Real' are 2,234.62 mg GA/kg FW and 1,743.47 mg GA/kg FW, respectively. These results were higher than ours. However, Lim et al. (2016) have reported that total polyphenol contents in 'Sulhyang' and 'Janghee' are 229.18 and 39.11 mg GAE/100 g FW, respectively. Chaves et al. (2017) have shown that total polyphenol contents in seven strawberry cultivars are in the range of $1.6 \sim 2.54 \mathrm{mg}$ TAE/g FW. These results were similar to ours.

In the present study, 'Josaenghongsim' had the highest total flavonoid contents at $599.56 \pm 9.82 \mathrm{mg} \mathrm{QE} / 100 \mathrm{~g} \mathrm{FW}$, followed by 'Mihong' at 288.28 $\pm 75.24 \mathrm{mg}$ QE/100 g FW and 'Seolhyang' at $202.00 \pm 2.34 \mathrm{mg} \mathrm{QE} / 100 \mathrm{~g}$ FW (Table 3). Significant $(p<0.05)$ differences in total flavonoid contents were found among strawberry cultivars. Lim et al. (2016) have reported that total flavonoid contents in 'Sulhyang' and 'Janghee' strawberrries

Table 3. Content of total polyphenols and flavonoids in 12 Korean strawberry cultivars.

\begin{tabular}{|c|c|c|}
\hline Sample & $\begin{array}{c}\text { Total polyphenol } \\
\text { contents } \\
\left(\mathrm{mg} \mathrm{TAE}^{1)} / 100 \mathrm{~g} \mathrm{FW}^{2)}\right)\end{array}$ & $\begin{array}{l}\text { Flavonoid contents } \\
\left(\mathrm{mg} \mathrm{QE}^{3)} / 100 \mathrm{~g} \mathrm{FW}\right)\end{array}$ \\
\hline Berrystar & $36.83 \pm 4.96^{\mathrm{ef} 4) 5)}$ & $17.57 \pm 0.01^{\mathrm{e}}$ \\
\hline Chodong & $61.01 \pm 6.01^{\mathrm{c}}$ & $16.80 \pm 0.10^{\mathrm{e}}$ \\
\hline Dahong & $61.01 \pm 17.1^{\mathrm{cd}}$ & $17.83 \pm 0.11^{\mathrm{e}}$ \\
\hline Dummy & $34.20 \pm 5.25^{\mathrm{ef}}$ & $19.41 \pm 0.10^{\mathrm{e}}$ \\
\hline Johong & $23.72 \pm 1.08^{f}$ & $125.78 \pm 5.39^{d}$ \\
\hline Josaenghongsim & $118.85 \pm 1.97^{\mathrm{a}}$ & $599.56 \pm 9.82^{\mathrm{a}}$ \\
\hline Manhyang & $21.7 \pm 0.64^{\mathrm{f}}$ & $17.38 \pm 0.01^{\mathrm{e}}$ \\
\hline Mihong & $56.35 \pm 15.11^{\mathrm{cde}}$ & $288.28 \pm 75.24^{b}$ \\
\hline Okme & $74.46 \pm 2.33^{\mathrm{b}}$ & $18.29 \pm 0.11^{\mathrm{e}}$ \\
\hline Seolhyang & $39.03 \pm 0.47^{\mathrm{ef}}$ & $202.00 \pm 2.34^{\mathrm{c}}$ \\
\hline Sinseolmae & $23.56 \pm 0.64^{\mathrm{f}}$ & $123.38 \pm 0.67^{d}$ \\
\hline Suhong & $42.75 \pm 3.81^{\mathrm{def}}$ & $220.53 \pm 18.97^{c}$ \\
\hline
\end{tabular}


are 52.32 and $39.11 \mathrm{mg} \mathrm{CE} / 100 \mathrm{~g}$, lower than ours. Bae et al. (2019) have reported that total flavonoid content in 'Sulhyang' is $546.12 \mathrm{mg} \mathrm{CHE} / 100 \mathrm{~g}$ sample, same as 'Josaenghongsim'. Kim et al. (2018) have determined antioxidant activities of various berries and reported that total flavonoid contents in raspberry and wild raspberry are 731.08 and $362.41 \mathrm{mg} \mathrm{QE} / 100 \mathrm{~g} \mathrm{FW}$, respectively, higher than our results. Lee et al. (2014) have shown that total flavonoid contents in wild raspberry were in the range of 10.91 14.90 mg QE/100 g FW, similar to our results. These findings indicate that total polyphenol and flavonoid contents are different according to the variety.

\subsection{Antioxidant activity}

Antioxidant activity was measured based on DPPH and ABTS free radical scavenging activities widely used to find antioxidants from various natural materials (Lee et al., 2014). DPPH free radical scavenging activity consists in the reduction of DPPH radical by substances present in the extraxt, leading to the formation of reduced $\mathrm{DPPH}-\mathrm{H}$, which changes in color from deep purple to loss of color (Chaves et al., 2017). DPPH free radial scavenging activities were measured using DPPH and expressed as trolox equivalent ( $\mu$ mol TEAC/100 g FW). DPPH free radial scavenging activities of 12 cultivars of strawberries used in this experiment were in the range of $1,381.7 \pm 12.7$ to $1,095.3 \pm 37.1 \mu \mathrm{mol}$ TEAC/100 g FW, with 'Josaenghongsim', 'Johong', 'Sinseolmae', 'Seolhyang', and 'Berrystar' having the highest values (Table 4$)$. Significant $(p<0.05)$ differences in DPPH free radial scavenging activity were found among strawberry cultivars. Nowicka et al. (2019) have determined DPPH free radical scavenging activities of 90 strawberries grown in Poland and found that the average activity is $751.57 \mu \mathrm{mol}$ TEAC/100g. Pineli et al. (2011) have reported that DPPH free radical scavenging activity of 'Osogrand' and 'Camino Real' are $12.83 \mu \mathrm{mol} \mathrm{TEAC/g}$ and $10.10 \mu \mathrm{mol} \mathrm{TEAC/g}$, respectively, somewhat lower than our results.

Another effective method to measure radical scavenging activity is the ABTS radical cation decolorization assay. This

Table 4. Antioxidant activities of 12 Korean strawberry cultivars.

\begin{tabular}{lcc}
\hline \multicolumn{1}{c}{ Sample } & $\begin{array}{c}\text { DPPH } \\
(\mu \text { mol TEAC1 }) / 100 \mathrm{~g} \\
\text { FW2 })\end{array}$ & $\begin{array}{c}\text { ABTS } \\
(\mu \mathrm{mol} \text { TEAC/100 g FW })\end{array}$ \\
\hline Berrystar & $1316.0 \pm 30.3^{\mathrm{a} 3) 4)}$ & $4715.7 \pm 5.8^{\mathrm{g}}$ \\
Chodong & $1207.5 \pm 18.7^{\mathrm{bc}}$ & $4732.3 \pm 20.8^{\mathrm{g}}$ \\
Dahong & $1178.2 \pm 56.6^{\mathrm{cd}}$ & $4472.7 \pm 5.5^{\mathrm{i}}$ \\
Dummy & $1145.1 \pm 23.2^{\mathrm{d}}$ & $4262.3 \pm 15.3^{\mathrm{h}}$ \\
Johong & $1364.0 \pm 20.6^{\mathrm{a}}$ & $5209.0 \pm 0.1^{\mathrm{c}}$ \\
Josaenghongsim & $1381.7 \pm 12.7^{\mathrm{a}}$ & $5052.7 \pm 11.8^{\mathrm{d}}$ \\
Manhyang & $1243.7 \pm 4.8^{\mathrm{b}}$ & $5239.0 \pm 10.0^{\mathrm{b}}$ \\
Mihong & $1095.3 \pm 37.1^{\mathrm{d}}$ & $4942.3 \pm 37.9^{\mathrm{f}}$ \\
Okme & $1126.8 \pm 13.4^{\mathrm{d}}$ & $4719.1 \pm 0.1^{\mathrm{g}}$ \\
Seolhyang & $1328.2 \pm 19.4^{\mathrm{a}}$ & $9179.0 \pm 1.0^{\mathrm{a}}$ \\
Sinseolmae & $1346.6 \pm 3.7^{\mathrm{a}}$ & $5019.0 \pm 10.0^{\mathrm{e}}$ \\
Suhong & $1114.6 \pm 45.2^{\mathrm{d}}$ & $5252.4 \pm 5.7^{\mathrm{b}}$ \\
\hline
\end{tabular}

1) TEAC: Trolox equivalent antioxidant capacity. ${ }^{2)}$ FW: fresh weight. ${ }^{3)}$ Values are mean \pm standard deviation $(n=3) .{ }^{4)}$ Values with different letters within the same row are significantly different by Duncan's multiple range test at $\mathrm{p}<0.05$. method can be used to obtain results in a short time. It can be applied to both hydrophobic and hydrophilic sample (Kim et al., 2019). ABTS free radial scavenging activities of 12 strawberry extracts were compared. Results are shown in Table 4. ABTS free radical scavenging activities of these extracts were in the range of $9,179.0 \pm 1.0$ to $4,262 \pm 15.3 \mu \mathrm{mol}$ TEAC/ $100 \mathrm{~g} \mathrm{FW}$, with 'Seolhyang' showing the highest activity, followed by Suhong, Manhyang, and Johong. There were significant $(p<0.05)$ differences in ABTS free radical scavenging activity among strawberry cultivars. Kim et al. (2016) have reported that ABTS free radical scavenging activities of raspberry and blackberry are $72 \mu \mathrm{mol} \mathrm{TE} / \mathrm{g}$ and $20 \mu \mathrm{mol} \mathrm{TE} / \mathrm{g}$, respectively, lower than ours. Lee et al. (2015) have reported that ABTS free radical scavenging activities of black raspberry, blueberry, and raspberry

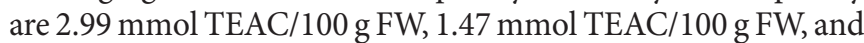
$0.77 \mathrm{mmol}$ TEAC/100 g FW, respectively. These results suggest that antioxidants present in these strawberry extracts could eliminate highly reactive free radicals to prevent oxidation of important biomolecules such as unsaturated fatty acids, genes, and proteins (Fan et al., 2011).

\subsection{Method validation}

- Analysis conditions HPLC analyses of ellagic acid contents in strawberries were performed using an Agilent HPLC system (Agilent Technology, Santa Clara, CA, USA). The mobile phase consisted of solvent A (tertiary distilled water containing $0.1 \%$ formic acid) and solvent B (acetonitrile). The flow rate for the mobile phase was set at $1 \mathrm{~mL} / \mathrm{min}$. UV detection was performed at wavelength of $254 \mathrm{~nm}$;

- Linearity, limit of detection (LOD), and limit of quantitation (LOQ) Standard calibration curves for ellagic acid standard by HPLC were obtained in the range of $10-100 \mu \mathrm{g} / \mathrm{mL}$ using five different concentrations $(n=3)$. Ellagic acid standard was used to calculate a linear regression equation with a correlation coefficient $\left(\mathrm{R}^{2}\right)$ of 0.9999 . LOD was found to be $2.35 \mu \mathrm{g} / \mathrm{mL}$ for ellagic acid standard and LOQ of the standard were found to be $7.13 \mu \mathrm{g} / \mathrm{mL}$. Thus, detection and quantification of ellagic acid are possible even if its amount is small (Table 5). Results of this study can be used to verify quantitative and detection limits of marker component analysis for the standardization of strawberry extract;

- Accuracy, precision, and recovery The precision of the optimized method using standard compounds was verified at three concentrations $(10,50$ and $100 \mu \mathrm{g} / \mathrm{mL}$ ). Relative standard deviations (RSDs) were $0.20-5.13 \%$ and $0.82-5.31 \%$ by HPLC for inter-day and intra-day variations $(n=3)$, respectively (Table 6). Regarding accuracy, the average recovery rate of ellagic acid was $99.0 \%$ to $100.1 \%$. RSD value was in the range of $0.8 \%$ to $5.3 \%$ (Table 7 ). Thus, the analytic method was confirmed to have excellent precision and accuracy.

- Stability and Contents Chemical stability of ellagic acid, a marker compound, was determined based on the change in content of ellagic acid at a concentration of $100 \mathrm{ug} / \mathrm{mL}$ after it was left at room temperature for 24 hours (Table 8). Results revealed that the average recovery rate of ellagic 
acid was $100.4 \%$. Its content change rate was $1.50 \%$ after 24 hours of storage at room temperature. Thus, ellagic acid was confirmed to have chemical stability for 24 hours at room temperature. Also, the ellagic acid content in all varieties of strawberries was found to be in the range of $12.8 \pm 0.2-16.6 \pm 0.3$, respectivlely (Table 9 ).

Table 5. Calibration curve, linearity, limit of detection (LOD), limit of quantitation (LOQ) of ellagic acid.

\begin{tabular}{ccccc}
\hline $\begin{array}{c}\text { Concentration } \\
(\mu \mathrm{g} / \mathrm{mL})\end{array}$ & $\begin{array}{c}\text { Regression } \\
\text { equation }\end{array}$ & $\mathrm{R} 2$ & $\begin{array}{c}\text { LOD } \\
(\mu \mathrm{g} / \mathrm{mL})\end{array}$ & $\begin{array}{c}\text { LOQ } \\
(\mu \mathrm{g} / \mathrm{mL})\end{array}$ \\
\hline $10-100$ & $\mathrm{y}=133.22 \mathrm{x}-320.63$ & 0.9999 & 2.35217 & 7.12778 \\
\hline
\end{tabular}

Table 6. Precision of ellagic acid

\begin{tabular}{|c|c|c|c|c|}
\hline \multirow{2}{*}{$\begin{array}{c}\text { Concentration } \\
(\mu \mathrm{g} / \mathrm{mL})\end{array}$} & \multicolumn{2}{|c|}{ Inter-day } & \multicolumn{2}{|c|}{ Intra-day } \\
\hline & $\begin{array}{c}\text { Mean } \pm \mathrm{SD}^{1)} \\
(\mu \mathrm{g} / \mathrm{mL})\end{array}$ & $\begin{array}{c}\mathrm{RSD}^{2)} \\
(\%)\end{array}$ & $\begin{array}{c}\text { Mean } \pm \text { SD } \\
(\mu \mathrm{g} / \mathrm{mL})\end{array}$ & $\begin{array}{l}\text { RSD } \\
(\%)\end{array}$ \\
\hline 10 & $9.83 \pm 0.50$ & 5.13 & $9.82 \pm 0.51$ & 5.31 \\
\hline 50 & $47.91 \pm 0.31$ & 0.66 & $47.55 \pm 0.42$ & 0.83 \\
\hline 100 & $96.56 \pm 0.19$ & 0.20 & $95.04 \pm 0.79$ & 0.82 \\
\hline
\end{tabular}

Table 7. Accuracy of ellagic acid.

\begin{tabular}{ccccc}
\hline $\begin{array}{c}\text { Spiked amount } \\
(\mu \mathrm{g} / \mathrm{mL})\end{array}$ & $\begin{array}{c}\text { measured amount } \\
(\mu \mathrm{g} / \mathrm{mL})\end{array}$ & $\begin{array}{c}\text { RSD } \\
(\%)\end{array}$ & $\begin{array}{c}\text { Recovery } \\
(\%)\end{array}$ & $\begin{array}{c}\text { Recovery } \\
\text { average }\end{array}$ \\
\hline 10 & $9.53 \pm 0.50$ & 5.3 & 93.8 & 100.0 \\
& & & 103.0 & \\
& & & 103.0 & \\
50 & $47.20 \pm 0.41$ & 0.9 & 98.0 & 99.0 \\
& & & 99.2 & \\
& & & 99.7 & \\
100 & $95.50 \pm 0.79$ & 0.8 & 99.7 & 100.1 \\
& & & 101.1 & \\
& & & 96.6 & \\
\hline
\end{tabular}

Recovery $(\%)=($ amount found-original amount $) /$ amount spiked $\times 100 \%$.

Table 8. Analytical result of ellagic acid stability test

\begin{tabular}{cccc}
\hline Compound & $0 \mathrm{~h}$ & $24 \mathrm{~h}$ & Recovery (\%) \\
\hline Ellagic acid & 95.04 & 96.41 & 100.4 \\
\hline
\end{tabular}

Table 9. Contents of ellagic acid in 12 Korean strawberry cultivars

\begin{tabular}{lc}
\hline \multicolumn{1}{c}{ Sample } & Ellagic acid Content $(\mu \mathrm{g} / \mathrm{mL})$ \\
\hline Berrystar & $15.1 \pm 0.1^{\mathrm{c} 12)}$ \\
Chodong & $15.1 \pm 0.2^{\mathrm{c}}$ \\
Dahong & $16.5 \pm 0.2^{\mathrm{a}}$ \\
Dummy & $14.2 \pm 0.2^{\mathrm{e}}$ \\
Johong & $16.1 \pm 0.0^{\mathrm{b}}$ \\
Josaenghongsim & $12.8 \pm 0.2^{\mathrm{f}}$ \\
Manhyang & $14.2 \pm 0.1^{\mathrm{e}}$ \\
Mihong & $14.8 \pm 0.1^{\mathrm{d}}$ \\
Okme & $16.6 \pm 0.3^{\mathrm{a}}$ \\
Seolhyang & $14.5 \pm 0.1^{\mathrm{e}}$ \\
Sinseolmae & $14.5 \pm 0.1^{\mathrm{e}}$ \\
Suhong & $16.6 \pm 0.1^{\mathrm{a}}$ \\
\hline${ }^{1)}$ Values are mean \pm standard deviation $(\mathrm{n}=3) ;{ }^{2)}$ Values with different letters within the \\
same row are significantly different by Duncans multiple range test at $\mathrm{p}<0.05$.
\end{tabular}

\section{Conclusions}

In this study, strawberry fruit extracts from 12 Korean cultivars showed high antioxidant activities. Such high activities are thought to be due to their high contents of total polyphenol and flavonoid that can inhibit oxidation of free radicals. Results of this study could be used as basic data for establishing a standard for determining the development potential and performing content analysis of strawberry extracts based on quantitative analysis using ellagic acid as a marker compound for the validation and standardization of natural antioxidants.

\section{Conflict of interest}

All of the authors agree with submission to FSB and we have no conflict of interest to declare.

\section{References}

Azzini, E., Vitaglione, P., Intorre, F., Napolitano, A., Durazzo, A., Foddai, M. S., Fumagalli, A., Catasta, G., Rossi, L., Venneria, E., Raguzzini, A., Palomba, L., Fogliano, V., \& Maiani, G.. (2010). Bioavailability of strawberry antioxidants in human subjects. The British Journal of Nutrition, 104(8), 1165-1173. http://dx.doi. org/10.1017/S000711451000187X. PMid:20487578.

Bae, M. J., Kim, E. N., Choi, H. K., Byun, K. H., Chung, K. H., Yoon, J. A., \& An, J. H. (2019). Quality characteristics and antioxidant activities of strawberries according to various extraction methods. Journal of the Korean Society for Food and Nutrition, 48(7), 728-738. http://dx.doi.org/10.3746/jkfn.2019.48.7.728.

Brand-Williams, W., Cuvelier, M. E., \& Berset, C. (1995). Use of a free radical method to evaluate antioxidant activity. LebensmittelWissenschaft + Technologie, 28(1), 25-30. http://dx.doi.org/10.1016/ S0023-6438(95)80008-5.

Chaves, V. C., Calvete, E., \& Reginatto, F. H. (2017). Quality properties and antioxidant activity of seven strawberry (Fragaria $\times$ ananassa Duch) cultivars. Scientia Horticulturae, 225, 293-298. http://dx.doi. org/10.1016/j.scienta.2017.07.013.

Fan, Z. L., Wang, Z. Y., \& Liu, J. R. (2011). Cold-field fruit extracts exert different antioxidant and antiproliferative activities in vitro. Food Chemistry, 129(2), 402-407. http://dx.doi.org/10.1016/j. foodchem.2011.04.091. PMid:30634244.

Giampieri, F., Tulipani, S., Alvarez-Suarez, J. M., Quiles, J. L., Mezzetti, B., \& Battino, M. (2012). The strawberry: composition, nutritional quality, and impact on human health. Nutrition (Burbank, Los Angeles County, Calif.), 28(1), 9-19. http://dx.doi.org/10.1016/j. nut.2011.08.009. PMid:22153122.

Halliwell, B., Gutteridge, J. M. C., \& Cross, C. E. (1992). Free radicals, antioxidants and human disease: where are we now? The Journal of Laboratory and Clinical Medicine, 119(6), 598-620. PMid:1593209.

Hwang, S. J., Yoon, W. B., Lee, O., Cha, S. J., \& Kim, J. D. (2014). Radicalscavenging-linked antioxidant activities of extracts from block chokeberry and blueberry cultivated in Korea. Food Chemistry, 146, 71-77. http:// dx.doi.org/10.1016/j.foodchem.2013.09.035. PMid:24176315.

Kim, H. H., Heo, M. R., Lee, S., \& Yim, S. H. (2019). Validation of analytical method and antioxidant properties of Eriobotrya japonica Lindl. leaf extract according to extraction solvent. Korean Journal of Food Science Technology, 51, 301-308.

Kim, J. S., Moon, Y. S., \& Kwak, E. J. (2018). Comparison of phenolic composition, content, and antioxidant activity in Raspberries and Blackberries. Weonye Gwahag Gisulji, 36, 115-127. 
Kim, K. S., Han, S. H., An, I. S., \& Ahn, K. J. (2016). Protective effects of ellagic acid against UVA-induced oxidative stress in human dermal papilla. Asian Journal of Beauty and Cosmetology, 14(2), 191-200. http://dx.doi.org/10.20402/ajbc.2016.0048.

Kim, S. K., Kim, D. S., Kim, D. Y., \& Chun, C. H. (2015). Variation of bioactive compounds content of 14 oriental strawberry cultivars. Food Chemistry, 184, 196-202. http://dx.doi.org/10.1016/j. foodchem.2015.03.060. PMid:25872444.

Korean Food and Drug Administration - KFDA. (2015). Analytical method guideline about validation of drugs and etc. (pp. 1-18). Seoul, Korea: KFDA.

Lee, H. H., Moon, Y. S., Yun, H. K., Park, P. J., \& Kwak, E. J. (2014). Contents of bioactive constituents and antioxidant activities of cultivated and wild Raspberries. Weonye Gwahag Gisulji, 32(1), 115-122. http://dx.doi.org/10.7235/hort.2014.13114.

Lee, S. H., \& Lee, S. O. (2016). Polyphenol contents and antioxidant activities of lentil extracts from different cultivars. Journal of the Korean Society of Food Science and Nutrition, 45(7), 973-979. http:// dx.doi.org/10.3746/jkfn.2016.45.7.973.

Lee, Y., Lee, J. H., Kim, S. D., Chang, M. S., Jo, I. S., Kim, S. J., Hwang, K. T., Jo, H. B., \& Kim, J. H. (2015). Chemical composition, functional constituents, and antioxidant activities of berry fruits produced in Korea. Journal of the Korean Society of Food Science and Nutrition, 44(9), 1295-1303. http://dx.doi.org/10.3746/jkfn.2015.44.9.1295.

Lim, S., Hwang, H., \& Shin, Y. (2016). Physicochemical properties and antioxidant activities of 'Selhyang' and 'Janghee' strawberries from different ripening stages grown in Korea. J East Asian Soc Diet Life, 26(1), 80-87. http://dx.doi.org/10.17495/easdl.2016.2.26.1.80.

Maas, J. L., Galletta, G. J., \& Stoner, G. D. (1991). Ellagic acid, and anticarcinogen in fruits, especially in strawberries: a review. HortScience, 26(1), 10-14. http://dx.doi.org/10.21273/HORTSCI.26.1.10.

Meyers, K. J., Watkins, C. B., Pritts, M. P., \& Liu, R. H. (2003). Antioxidant and antiproliferative activities of strawberries. Journal of Agricultural and Food Chemistry, 51(23), 6887-6892. http://dx.doi.org/10.1021/ jf034506n. PMid:14582991.

Moreno, M. I. N., Isla, M. I., Sampietro, A. R., \& Vattuone, M. A. (2000). Comparison of the free radical-scavenging activity of propolis from several regions of Argentina. Journal of Ethnopharmacology, 71(12), 109-114. http://dx.doi.org/10.1016/S0378-8741(99)00189-0. PMid:10904153.

Mukhtar, H., Das, M., \& Bickers, D. R. (1986). Inhibition of 3-methylcholanthrene-induced skin tumorigenicity in BALB/c mice by chronic oral feeding of trace amounts of ellagic acid in drinking water. Cancer Research, 46(5), 2262-2265. PMid:3486036.

Nowicka, A., Kucharska, A. Z., Sokół-Łętowska, A., \& Fecka, I. (2019). Comparison of polyphenol content and antioxidant capacity of strawberry fruit from 90 cultivars of Fragaria $\times$ ananassa Duch. Food Chemistry, 270, 32-46. http://dx.doi.org/10.1016/j.foodchem.2018.07.015. PMid:30174053.

Papoutsi, Z., Kassi, E., Tsiapara, A., Fokialakis, N., Chrousos, G. P., \& Moutsatsou, P. (2005). Evaluation of estrogenic/antiestrogenic activity of ellagic acid via the estrogen receptor subtypes ERa and
ER $\beta$. Journal of Agricultural and Food Chemistry, 53(20), 7715-7720. http://dx.doi.org/10.1021/jf0510539. PMid:16190622.

Pineli, L. L. O., Moretti, C. L., dos Santos, M. S., Campos, A. B., Brasileiro, A. V., Córdova, A. C., \& Chiarello, M. D. (2011). Antioxidants and other chemical and physical characteristics of two strawberry cultivars at different ripeness stages. Journal of Food Composition and Analysis, 24(1), 11-16. http://dx.doi.org/10.1016/j.jfca.2010.05.004.

Scalzo, J., Politi, A., Pellegrini, N., Mezzetti, B., \& Battino, M. (2005). Plant genotype affects total antioxidant capacity and phenolic contents in fruit. Nutrition (Burbank, Los Angeles County, Calif.), 21(2), 207213. http://dx.doi.org/10.1016/j.nut.2004.03.025. PMid:15723750.

Seeram, N. P., Adams, L. S., Zhang, Y., Lee, R., Sand, D., Scheuller, H. S., \& Heber, D. (2006). Blackberry, black raspberry, blueberry, cranberry, red raspberry, and strawberry extracts inhibit growth and stimulate apoptosis of human cancer cells in vitro. Journal of Agricultural and Food Chemistry, 54(25), 9329-9339. http://dx.doi. org/10.1021/jf061750g. PMid:17147415.

Shimogaki, H., Tanaka, Y., Tamai, H., \& Masuda, M. (2000). In vitro and in vivo evaluation of ellagic acid on melanogenesis inhibition. International Journal of Cosmetic Science, 22(4), 291-303. http:// dx.doi.org/10.1046/j.1467-2494.2000.00023.x. PMid:18503416.

Sies, H. (1993). Strategies of antioxidant defense. European Journal of Biochemistry, 215(2), 213-219. http://dx.doi.org/10.1111/j.1432-1033.1993. tb18025.x. PMid:7688300.

Singleton, V. L., Orthofer, R., \& Lamuela-raventos, R. M. (1999). Analysis of total phenols and other oxidation substrate and antioxidants by means of Folin-Ciocalteu reagent. Methods in Enzymology, 299, 152-178. http://dx.doi.org/10.1016/S0076-6879(99)99017-1.

Thaipong, K., Boonprakob, U., Crosby, K., Cisneros-Zevallos, L., \& Hawkins Byrne, D. (2006). Comparison of ABTS, DPPH, FRAP, and ORAC assays for estimating antioxidant activity from guava fruit extracts. Journal of Food Composition and Analysis, 19(6-7), 669-675. http://dx.doi.org/10.1016/j.jfca.2006.01.003.

Tosun, M., Ercisli, S., Karlidag, H., \& Sengul, M. (2009). Characterization of red raspberry (Rubus idaeus L.) genotypes for their physicochemical properties. Journal of Food Science, 74(7), C575-C579. http://dx.doi. org/10.1111/j.1750-3841.2009.01297.x. PMid:19895463.

Türk, G., Sönmez, M., Ceribași, A. O., Yüce, A., \& Ateșşahin, A. (2010). Attenuation of cyclosporine A-induced testicular and spermatozoal damages associated with oxidative stress by ellagic acid. International Immunopharmacology, 10(2), 177-182. http://dx.doi.org/10.1016/j. intimp.2009.10.013. PMid:19883798.

Xu, Y. M., Deng, J. Z., Ma, J., Chen, S. N., Marshall, R., Jones, S. H., Johnson, R. K., \& Hecht, S. M. (2003). DNA damaging activity of ellagic acid derivatives. Bioorganic \& Medicinal Chemistry, 11(7), 1593-1596. http://dx.doi.org/10.1016/S0968-0896(02)00452-2. PMid:12628683.

Yong, Y. S., Lee, S., Byun, N. Y., Sun, S., Kim, M. J., Jang, S. W., Jang, W. S., Lee, S. Y., \& Yim, S. H. (2019). Antioxidant activities and validation of analytical method of marker compounds in strawberry fruits from various cultivars. Korean Journal of Food Science Technology, $51,517-523$ 